The range maps cover Alberta and show the area within the province where you can see the plant. This is useful because it shows over $35 \%$ of Alberta's species are confined to the southern border with British Columbia and the United States. As the maps are small $(1 \times$ $2 \mathrm{~cm}$ ) they require some interpretation. I photographed a Striped Coralroot in Bow Valley Provincial Park, so I verified that the range map showed this plant at this location. It does, but it required careful examination and analysis due to the size. The other distributions are equally valid.

There is also a key arranged by leaf structure and flower colour. This uses thumbnail ( $3 / 4 ")$ photos of the families. So Violas appear in the white, yellow and purple sections. Is this enough to satisfy the ladies?

Despite my clear preference for Plants as a book, I would say that both of these books are good guides. The photographs are excellent and the text, while very different in style, gives solid information. Your choice should be dictated by your intentions or location. Alternatively, and this I suggest is the best idea, you could buy both as both, are good value for money.

ROY JOHN

2193 Emard Crescent, Beacon Hill North, Ottawa, Ontario K1J 6K5 Canada

\title{
Miscellaneaous
}

\section{Pilgrimage to Vallombrosa: From Vermont to Italy in the Footsteps of George Perkins Marsh}

By John Elder. 2006. University of Virginia Press, Charlottesville, Virginia, USA. xv +282 pages. U.S. \$29.95 Cloth.

This book is a story of pilgrimage, of memory, of hope. It's a beautiful book, a book of life, of family, of nature and culture. John Elder, a professor of English at Vermont's Middlebury College, invites the reader on a pilgrimage. It is a story of connections; from the second and third growth sugar bush hills of Vermont to the centuries-old, culturally prestigious forests of Vallombrosa in the Tuscany hills; from the sugar bush to the olive grove; from Robert Frost to Dante.

Vermont-born George Perkins Marsh was Abraham Lincoln's diplomat to the new Kingdom of Italy from 1861 until his death in 1882. Considered to be America's first environmentalist, Marsh was the author of the celebrated Man and Nature (1864). Inspired by his study of the rise and fall of Mediterranean cultures and his extensive experience of the region, Marsh's manifesto focused on environmental decline as central to the collapse of these once powerful cultures. Marsh was the first to describe and document the drastic, long-term impact of deforestation on civilization. His Man and Nature stirred the American imagination as America itself experienced the wave of deforestation flowing from east to west across the American landscape.

A sabbatical year permitted Elder and his wife to set out on a pilgrimage across France and Italy. Elder's purpose was to pursue the footsteps of Marsh who died in Vallombrosa in 1882. A pilgrimage usually has a set route, but novelty and surprise are to be expected. A pilgrimage on foot always becomes a pilgrimage of the heart and of the mind. Elder skillfully invites the reader on a pilgrimage of ideas, one that examines our place in nature.

Elder divides his pilgrimage into three landscapes, each connected to Marsh's vision of conservation. First is the journey to and within Tuscany, the crucible of
Marsh's thinking in the city of Florence, the surrounding hill towns and the celebrated forests of Vallombrosa. Second, is the literary landscape where Elder situates Marsh within the lineage of William Wordsworth, Matsuo Bashô and Robert Frost. The final section returns to Vermont, to Marsh's native Woodstock, the sugar bush of the Elder family, and to the Vermont-wide conservation initiatives.

Those who set out on a pilgrimage usually have a destination in mind. But that is often the only sure thing about a pilgrimage. It's what happens in between that counts and that often surprises. Nothing is hard and fast for Elder, nothing black-or-white. He writes skillfully of what he terms the "middle landscape," that ecotone where wilderness and civilization meet. It is upon that middle ground that Elder chooses to focus, weaving the theme of "stewardship" throughout his work.

The term "stewardship" has fallen on hard times in certain intellectual circles. Its anthropocentric connotations are too aristocratic, too old-fashioned for some. Not so for Elder, who calls for a mutuality of human history and natural history. He calls for preservation of not only biodiversity but also human values and community, a place where technology and religious faith both have their own special role to play. For Elder, the environmental crisis is ultimately a crisis of culture, a crisis of the human soul, a crisis of the human heart. Stewardship, brought into proper dialogue with contemporary ecological, feminist, religious and social justice thought, can engender the cultural and moral resources necessary to address the environmental needs of our time.

Elder's attempt to re-frame the discussion is welcome. Too often has environmental conversation fractured into dualistic dichotomies, into opposing camps of nature and culture. We need both voices to forge a social ecology, where ecosystems are not considered in the absence of culture and vice-versa. It's that middle ground that provides the vital connection between 
remote regions of wilderness and the places were we live, work and play.

We must thank Elder for eschewing sectarian language. His goal takes much more effort. It seeks a common ground that does not reduce to the lowest common denominator. The built environment, the cultivated environment, the wilderness environment; they all have a voice that needs to be heard. Elder speaks in the tradition of Aldo Leopold, René Dubos and Wendell Berry, voices that seek a dialogue between culture and the wild. For all three, the steward is the facilitator of such a needed task. The steward lives in that "boundary zone where the wilderness ethic may engage with recent developments of environmental history, and where the ideal of preservation transcending our narrow utilitarianism may engage with the tradition of stewardship." (page 218)

This is marvellous meditation. It's no wonder, since Elder's trade and tackle are words and stories. He weaves a story, a meditation, a contemplation that opens up our mind and heart to new possibilities for our relationship to forests, to those wild and wonderful places. It is a story of people tending the olive groves under the warm Tuscany sun, and of his own family's stewarding of the sugar maple groves of their Vermont

\section{Where to Watch Birds - World Cities}

By Paul Milne. 2007. Yale University Press P.O. Box 209040, New Haven, Connecticut 06520-9040 USA. 496 pages. U.S. 28.00 Paper.

This type of book is a reviewer's dream. Before you open it you know the author, Paul Milne, must make choices and these will not be the same as your choices. This means you know you will have the opportunity to criticize. So how well do his choices match those I would have made? First he has included only one Canadian city, Toronto. It is Canada's largest city but it is not the capital nor the best for the naturalist. One out of the 60 cities covered in the book seems a little thin for second largest country in the world [even if we rank $36^{\text {th }}$ for population]. Putting my obvious bias aside, I noted that other key cities are missing. Oslo, with its great royal park, and Kiev, a city of wonderful chestnut trees, are two evident examples. Indeed 60\% of the cities are in Europe and Asia; a disproportionate number for these two continents over North and South America and Australia.

Accepting the author's choices, how useful is this book? First this book covers more than the city itself. When I visit Victoria, British Columbia, I get up at dawn and walk from my downtown hotel through Beacon Hill park to the coast. I return before breakfast and then go to my meeting. These two hour jaunts have netted me some very interesting birds [e.g. Ancient Murrelet]. These activities were all within the downtown core of Victoria and did not involve any travel. The author includes in his version of "city" many areas that home. Landscape and culture provide the nexus of discussion. Forgetting one or the other dehumanizes us and sets the stage for either pillage or misanthropism.

In this era of apocalyptic predictions, environmental and social haemorrhaging, a widening gap between culture and nature, between rich and poor, urban and rural, Elder sets out a path of reconciliation, a path that seeks the common good. It's a path laced with community, dialogue, a sense of the sacred, good work, justice, stewardship, care and respect. These virtues don't come easily.

A final word to Elder: "I have come to believe that without the stories that integrate the face of nature with the drama of our human lives, society will not have the power to restrain our appetite and respect the larger balance of nature." (page 67) If you accept this conclusion, read this book. It will draw you into a world of memory and elegance. If you don't agree with Elder, read this book anyway. The full, inclusive fare offered by Elder will call you into a respectful dialogue.

JOHN MCCARTHY

Ecology Project, Ignatius Jesuit Centre of Guelph, P.O. Box 1238, Guelph, Ontario N1H 6N6 Canada

require significant travel - you will need a car. The equivalent of me driving to Goldstream Park, 17 kilometres from downtown Victoria, and more. Indeed some sites are over $100 \mathrm{~km}$ away (distances are given in the measurement used in the country; e.g., they are in miles in the U.S. and kilometres in Canada.)

Accepting the author's broad boundaries how useful is this book? I would say very useful indeed. I have birded in almost half of the cities mentioned [generally without a car] and have visited many of the sites he describes. He has an introductory section that explains the city in birder's terms and has a good section on transportation. Where there is a good public transportation to suitable birding locations (e.g., London, Moscow) the author provides enough information to get the traveller started. The site descriptions are clear and accurate and I wish I had owned this book years ago. There are locator maps where they are appropriate. There is a list of birds typically seen at each location. This worked well for all places and I verified with my notes that I too had seen a similar list of species.

I can quibble on some minor points. For example, under Johannesburg he includes Suikerbosrand [upland species - about $70 \mathrm{~km}$ from Johannesburg] but omits the nearby Pilansburg - perhaps the best park to visit [lowland species - about 100+ km from Johannesburg]. His information on travel omits to say it would be almost suicidal for a tourist to drive in Mumbai. Taxis are cheap and you can get a car and driver, sympathetic to your needs, from the Bombay Natural His- 